Article

\title{
The Impact of the Amount of Water Used in Activation Solution and the Initial Temperature of Paste on the Rheological Behaviour and Structural Evolution of Metakaolin-Based Geopolymer Pastes
}

\author{
Laura Vitola $^{1}$ (D) Ina Pundiene ${ }^{2, *}$, Jolanta Pranckeviciene ${ }^{2}$ and Diana Bajare ${ }^{1}$ \\ 1 Institute of Materials and Structures, Riga Technical University, 1658 Riga, Latvia; \\ laura.vitola_1@rtu.lv (L.V.); diana.bajare@rtu.lv (D.B.) \\ 2 Institute of Building Materials, Vilnius Gediminas Technical University, 10223 Vilnius, Lithuania; \\ jolanta.pranckeviciene@vgtu.lt \\ * Correspondence: ina.pundiene@vgtu.lt
}

Received: 5 September 2020; Accepted: 3 October 2020; Published: 6 October 2020

\begin{abstract}
This study aimed to determine the impact of the initial temperature of the paste (from $5{ }^{\circ} \mathrm{C}$ to $35^{\circ} \mathrm{C}$ ) and the addition of water, which reflects a decrease in the molarity of activation solutions (AS) by diluting $10 \mathrm{M} \mathrm{NaOH}$ with distillate water, on the rheological properties of geopolymer pastes. Additionally, this resulted in changes to the physical-mechanical properties of geopolymers after curing. A higher amount of water in the AS composition and higher initial paste temperature led to an increase in the spread values up to $28 \%$ and decreases viscosity. A smaller amount of water in the AS composition and a higher initial paste temperature accelerated the speed of the geopolymer structure formation up to 1.5 times during the curing period, increased compressive strength and reduced apparent porosity and pore size. X-ray diffraction confirmed the compressive strength test results and revealed that the lower amount of water in the AS and the higher initial paste temperature for the geopolymer preparation significantly affected the mineral formation and physical and mechanical properties of the samples.
\end{abstract}

Keywords: geopolymer; workability; compressive strength; initial temperature

\section{Introduction}

Based on numerous studies conducted in recent years, geopolymer binders are considered to be sustainable and environmentally friendly cementitious materials and are attractive in terms of their good cost-performance ratio due to low energy consuming production process and use of secondary raw materials instead of virgin ones [1,2].

Millions of tons of industrial wastes are being stored and disposed in landfills annually creating a pollution risk. The environmental aspect is a great driver to initiate as human society strives for cleaner production by finding opportunities for re-cycling of waste materials instead of landfilling. Disposal of industrial waste also requires the use of land, which can be potentially utilized for agricultural purposes or other needs. Reuse of secondary raw materials in production of alkali-activated aluminosilicate materials could not only expand the raw material base of the construction industry without increasing the use of natural mineral resources, but also reduce the effect of greenhouse gases associated with ordinary Portland cement and concrete production. Production of geopolymers requires significantly less energy than the production of Portland cement [3-6]. In addition, Portland cement-based concrete is subject to certain durability problems, including aggregate-alkali reactions, chloride-induced corrosion 
in reinforcing steel, retarded ettringite and thaumasite formation [7], which are not characteristic for geopolymers.

The proportion of the raw materials, viscosity of the fresh mixes and molarity of the alkaline activation solutions for geopolymer synthesis can be varied over a wide range, depending on the chemical and mineralogical composition of the precursors, which can also alter the reaction kinetics, chemical properties and microstructure of the geopolymers [8]. Hydroxide solutions with different molarities, as well as mixes of hydroxides and sodium silicates, are most frequently used as alkaline activation solutions to generate a high $\mathrm{pH}$ and activate source materials [9]. In cases where the molarity of the alkaline activation solution is insufficient (for example, the molarity of $\mathrm{NaOH}$ is less than $1 \mathrm{M}$ ), incomplete ion dissociation can occur, which results in an insufficient amount of intermediate from which new compounds can be formed. Alternatively, the opposite-if the molarity of the alkaline activation solution is too high (greater than $15 \mathrm{M}$ ), dissolved products can form a layer around unreacted particles restricting or significantly slowing ion dissociation. Even if an undesirable layer is established around the particles, it has been found that the geopolymerization process does not happen completely, which results in a lower mechanical strength of the material $[10,11]$.

Some studies show an important effect of the alkaline activation solution on the rheology of geopolymer paste [9,12] that plays a key role in its practical applications [13]. In particular, $\mathrm{NaOH}$-activated slag pastes behave as Bingham fluid $[9,14]$, while slag pastes activated by using a sodium silicate solution alone-fit the Herschel-Bulkley model $[9,12]$. In most cases, a higher water/alkaline ratio of the activation solution improves the flowability and workability of the paste [15]. The size, shape and other geometrical properties of the precursor's particles effect the rheological properties of the fresh geopolymer paste [16]. Mixing time and mixing speed have an influence on the rheology of geopolymer pastes as well. According to the research of Kaur et al. [16], the active mixing of raw materials results in increased viscosity of the paste and improved mechanical properties of the hardened samples. This is explained by the input of mixing energy, which can partially break down the size of the raw material "aggregates" which can occur due to agglomeration of the powdered raw materials during milling to allow the complete reaction to continue. Mixing is also a temperature-dependent process, which is influenced by the activation energy of raw materials used for geopolymer production. The viscosity and geopolymerisation reaction rate depends on the paste temperature because Brownian motion is slowing down and the dissolution rate of aluminum decreases at lower temperatures $[9,16]$.

It is reported that the higher molarity of activation solution made of sodium hydroxide increases the viscosity of the mixture, which results in the increased strength of the hardened samples $[15,17]$. Moreover, regardless of the alkaline activation solutions used $\left(\mathrm{NaOH}, \mathrm{Na}_{2} \mathrm{CO}_{3}\right.$ or sodium silicate solution), an increased concentration of $\mathrm{Na}_{2} \mathrm{O}$ in the activation solution increases the viscosity of the mixture [18]. Furthermore, when sodium silicate solution is used as the alkaline activation solution, a rise in the $\mathrm{SiO}_{2}-\mathrm{Na}_{2} \mathrm{O}$ ratio decreases the workability of the geopolymer paste $[9,18,19]$. There is an opinion that the water in a geopolymer mixture does not play any role in the chemical reaction and merely provides for the workability of the paste [8], but other studies discuss the positive effects of water retention on the geopolymerisation process and on the final properties of metakaolin-based and fly ash-based geopolymers [20-22].

However, a higher water/alkaline ratio in the activation solution can negatively affect the formation of the geopolymer structure, pore structure, mechanical properties and durability, as well as the modulus of elasticity, due to the increased pore volume and pore size [23,24].

The water in the micro-structure of the geopolymers accumulates in the pores, providing only alkaline transfer functions; it is not directly involved in the geopolymerisation process [25] but has an effect on the rheological properties of the material [26,27]. The decrease in workability of the geopolymer paste is associated with an increase in the molarity of the activation solution $[17,28]$. Koutnik et al. [24] conclude that the viscosity of the geopolymer paste, and later compressive strength of the specimens, strongly depends on the amount of filler (sand) and additional water used in the 
composition: increasing the amount of water results in a decrease in viscosity and compressive strength. On the contrary, when the water content of the composition is decreased from $45 \%$ to $30 \%$, the viscosity increases from $0.68 \mathrm{~Pa} \cdot \mathrm{s}$ to $8.1 \mathrm{~Pa} \cdot \mathrm{s}$ - that is, 12 times higher-and the compressive strength increases from $11 \mathrm{MPa}$ to $85 \mathrm{MPa}$, which is eight times higher.

Only a few studies discuss the influence of decreasing the alkaline solution molarity by diluting it with water to obtain better workability of the mixture or the properties of the hardened geopolymers after the initial curing at an elevated temperature and prolonged curing time at room temperature [29]. A higher water/alkaline ratio in the alkaline activation solution can negatively affect the structure of the geopolymers by increasing the size of the dominant pores and total porosity, which decreases its mechanical properties and reduces long-term durability [30,31].

Although viscosity is an important property affecting fluidity, workability and applicability of geopolymer paste, only a few detailed studies have been published clarifying this complex issue $[9,19,20]$.

The rheological properties of geopolymer pastes depend on the ratio of water to alkaline in the activation solutions and can strongly influence durability of the hardened geopolymers. This is important for adapting geopolymer compositions for practical use in construction sites in ambient temperatures, which depend on the weather conditions and period of year.

The present study aims to ascertain the effects of the alkaline activation solution, which is diluted with a certain amount of water, and the initial temperature $\left(5^{\circ} \mathrm{C}-35^{\circ} \mathrm{C}\right)$ of the raw materials on the rheological behavior of geopolymer pastes and their structural evolution during initial curing at an elevated temperature and curing at room temperature for 28 days. The mechanical properties of samples prepared from pastes with initial temperatures between $5{ }^{\circ} \mathrm{C}$ and $35^{\circ} \mathrm{C}$ were evaluated. The results of the study may make a significant contribution to the development of a knowledge in sustainable geopolymer creation.

\section{Materials and Methods}

\subsection{Raw Materials}

In this study waste metakaolin powder (MK) from Stikloporas Ltd., Lithuania was used as the source of aluminum silicate for geopolymer production. The MK is generated during foam glass pellet processing at a temperature of $820-850^{\circ} \mathrm{C}$. In the provided X-ray diffractogram (Figure 1), the most intensive crystalline phase of MK is quartz minerals. The specific surface area of MK is $892 \mathrm{~m}^{2} / \mathrm{kg}$ and the chemical composition (in mass \%) is: $\mathrm{SiO}_{2}-46.1, \mathrm{Al}_{2} \mathrm{O}_{3}-37.2, \mathrm{Fe}_{2} \mathrm{O}_{3}-1.10, \mathrm{CaO}-0.20$, $\mathrm{MgO}-0.20, \mathrm{~K}_{2} \mathrm{O}+\mathrm{Na}_{2} \mathrm{O}-0.7, \mathrm{TiO}_{2}-0.70$ and others-13.8. The MK consists of thin flake-shaped particles with a size between $1 \mu \mathrm{m}$ and $20 \mu \mathrm{m}$.

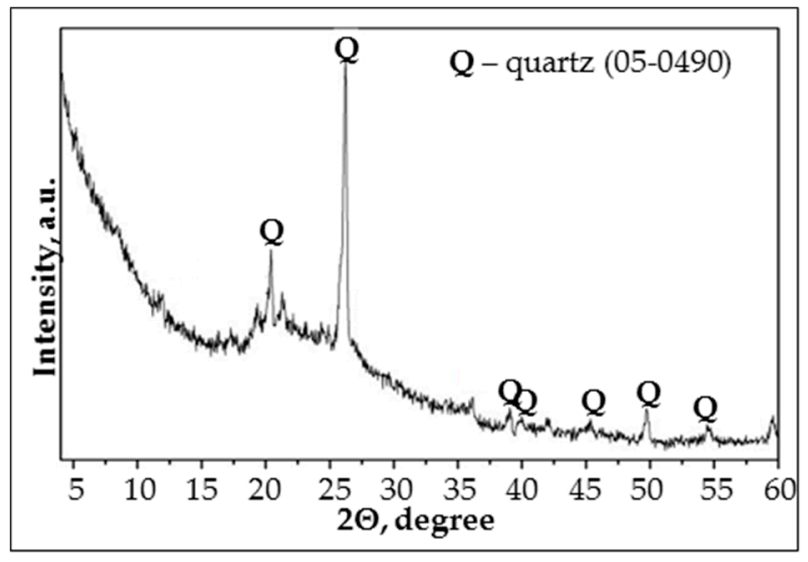

Figure 1. X-ray diffractogram of the metakaolin. 
To ensure the geopolymerisation process, commercially available sodium hydroxide flakes produced by Tianye Chemicals were used for the alkaline solution preparation. The alkaline solutions (AS) were obtained by diluting $10 \mathrm{M} \mathrm{NaOH}$ with distilled water. The water/10 $\mathrm{M} \mathrm{NaOH}$ ratio was from 0.6 to 1.8. The amount of $\mathrm{NaOH}$ in all activation solutions stayed the same, but the amount of water differed to detect the effect of water on the rheological properties of the paste as well as on the mechanical and physical properties of the hardened specimens.

\subsection{Mixture Design and Sample Preparation}

Fresh pastes were prepared according to the mixture design given in Table 1. The mass proportion of MK and $10 \mathrm{M} \mathrm{NaOH}$ was constant for all compositions (1.00/0.25). The activation solution (AS) was prepared from the $10 \mathrm{M} \mathrm{NaOH}$ by adding distilled water in a ratio of $0.25 / 0.15 \div 0.45$ and mixing for $30 \mathrm{~min}$ with a magnetic mixer. Before use, all raw materials were maintained at temperatures of $5{ }^{\circ} \mathrm{C}$, $15^{\circ} \mathrm{C}, 25^{\circ} \mathrm{C}$ and $35^{\circ} \mathrm{C}$ for $24 \mathrm{~h}$. The fresh paste containing AS and MK was prepared at the standard room temperature of $+20 \pm 1{ }^{\circ} \mathrm{C}$ by mixing for 3 min using a hand mixer with $140 \mathrm{rpm}$. Physical and mechanical properties were studied for three selected compositions: MK0.6, MK1.0 and MK1.4, prepared from the pastes with different initial temperatures depending on the temperature of the raw materials.

The paste was filled into metallic molds $(70 \times 70 \times 70 \mathrm{~mm})$, covered with plastic and immediately placed in a pre-heated curing chamber at a temperature of $80^{\circ} \mathrm{C}$ for $24 \mathrm{~h}$. The samples were weighed and ultrasonic pulse velocity (UPV) was measured during curing after 2, 4, 6, 8, 22 and $24 \mathrm{~h}$. The material density, UPV and compressive strength of the samples were measured after $24 \mathrm{~h}$ of curing at $80^{\circ} \mathrm{C}$, as well as after curing at room temperature at days $7,14,28$ and 56.

Table 1. Compositions of studied samples.

\begin{tabular}{|c|c|c|c|c|c|c|}
\hline \multirow{2}{*}{ Name of Composition } & \multicolumn{3}{|c|}{ Mixture Design, Mass Part } & \multirow{2}{*}{ Water/10 M NaOH Ratio } & \multirow{2}{*}{ Molarity } & \multirow{2}{*}{ AS/MK } \\
\hline & Metakaolin (MK) & $10 \mathrm{M} \mathrm{NaOH}$ & Water & & & \\
\hline M0.6 & \multirow{6}{*}{1.00} & \multirow{6}{*}{0.25} & 0.15 & 0.6 & 8.7 & 0.40 \\
\hline M0.8 & & & 0.20 & 0.8 & 8.3 & 0.45 \\
\hline M1.0 & & & 0.25 & 1.0 & 8.0 & 0.50 \\
\hline M1.4 & & & 0.35 & 1.4 & 7.4 & 0.60 \\
\hline M1.6 & & & 0.40 & 1.6 & 7.1 & 0.65 \\
\hline M1.8 & & & 0.45 & 1.8 & 6.9 & 0.70 \\
\hline
\end{tabular}

\subsection{Methods of Testing}

The electrical conductivity was performed using the MPC 227 instrument manufactured by Mettler-Toledo (EC electrode InLab 730, measuring range $0 \mathrm{mS} / \mathrm{cm}-1000 \mathrm{mS} / \mathrm{cm}$ ). The electrical conductivity of geopolymer pastes with initial temperatures of $5{ }^{\circ} \mathrm{C}, 15^{\circ} \mathrm{C}, 25^{\circ} \mathrm{C}$ and $35^{\circ} \mathrm{C}$ was measured immediately after mixing at standard room temperature $\left(20 \pm 1{ }^{\circ} \mathrm{C}\right)$.

The viscosity was tested using the vibro-viscometer SV-10 to define the dynamic viscosity of pastes up to $12,000 \mathrm{mPa} \cdot \mathrm{s}$ with $0.01 \mathrm{mPa} \cdot \mathrm{s}$ accuracy for a small amount of paste ( $35 \mathrm{~mL}$ ). The viscosity resistance of the paste was measured using the constant vibration of gauge plates at $30 \mathrm{~Hz}$ frequency, where viscosity resistance force was converted into an electrical signal and recorded. The tests were conducted at room temperature $\left(20 \pm 1{ }^{\circ} \mathrm{C}\right)$. The dynamic viscosity of fresh geopolymer pastes was measured immediately after mixing. The fluidity of geopolymer pastes was determined using the mini-slump test after mixing. To perform the mini-slump test, the paste was transferred into a cone (height $80 \mathrm{~mm}$, upper diameter $90 \mathrm{~mm}$, bottom diameter $100 \mathrm{~mm}$ ) and placed on a glass plate. Measurements were repeated five times and the diameter of the paste was measured in two directions. The fluidity was measured immediately after mixing the paste and at $10 \mathrm{~min}$ and $20 \mathrm{~min}$. 
The development of the geopolymer structure was evaluated by using the UPV method with the Pundit 7 tester. Specimens were placed between two ultrasonic transducers (transmitter and receiver) operating at $54 \mathrm{kHz}$. The transducers were pressed against the specimens at two strictly opposite points. Vaseline was used to ensure good contact. The UPV (V) was calculated using Equation (1):

$$
\mathrm{V}=1 / \tau \times 10^{6}
$$

where 1 is the distance between the cylindrical heads and $\tau$ is the time of the pulse spread.

Material density and compressive strength were tested in accordance with EN 1097-6 and EN 196-1. The open porosity was determined by water absorption, considering the volume of the prepared specimens.

The pore size distribution was evaluated using a Pore Master PM33-12 porosimeter; the testing sample was taken from the internal layer of the specimens.

The mineralogical composition of the MK and the obtained geopolymer samples was determined using the X-ray diffraction (XRD) patterns of the powdered 28-day old samples. Data were recorded by a DRON-7 diffraction meter (Cu anode, Ni filter, anode operating voltage of $30 \mathrm{kV}$, anode emission current of $12 \mathrm{~mA}$, goniometer apertures $(0.5 ; 1.0 ; 1.5 \mathrm{~mm})$ ).

\section{Results and Discussion}

\subsection{Viscosity of Alkali Activation Solution (AS) and Water at Different Temperatures}

The dynamic viscosity depended on the initial temperature of the $10 \mathrm{M} \mathrm{NaOH}$ that was used for the preparation of the AS (Figure 2). The dynamic viscosity was studied in order to evaluate viscosity behavior of the AS and its impact on the viscosity of geopolymer pastes. The increase in temperature from $5^{\circ} \mathrm{C}$ to $35^{\circ} \mathrm{C}$ led to a significant (five-fold) decrease of $10 \mathrm{M} \mathrm{NaOH}$ viscosity. The viscosity of $10 \mathrm{M}$ $\mathrm{NaOH}$ at $5{ }^{\circ} \mathrm{C}$ was $33 \mathrm{mPa} \cdot \mathrm{s}$; at $15^{\circ} \mathrm{C}$ it was $13.1 \mathrm{mPa} \cdot \mathrm{s}$; at $25^{\circ} \mathrm{C}-9.0 \mathrm{mPa} \cdot \mathrm{s}$; and at $35^{\circ} \mathrm{C}$ the viscosity decreased to $6.5 \mathrm{mPa} \cdot \mathrm{s}$. The viscosity decreased two-fold for distilled water and then temperature increases from $5{ }^{\circ} \mathrm{C}$ to $35^{\circ} \mathrm{C}$.

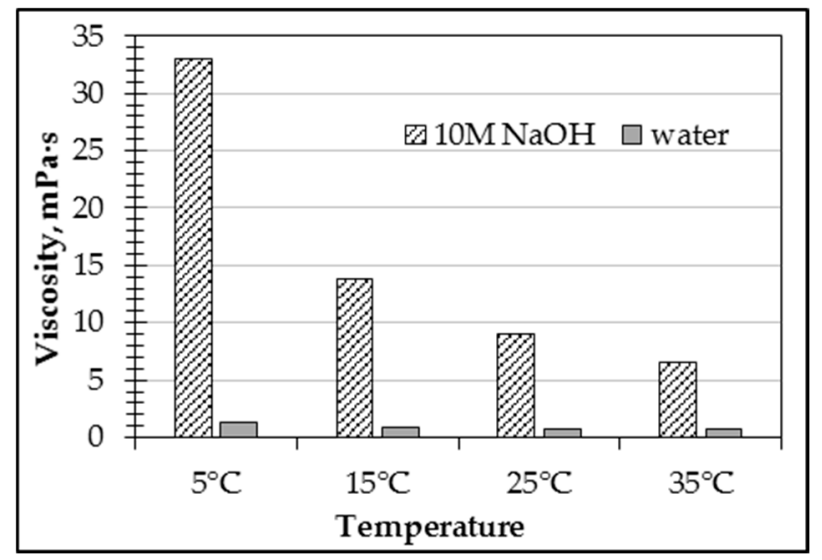

Figure 2. The viscosity of $10 \mathrm{M} \mathrm{NaOH}$ and distilled water at different temperatures.

\subsection{Electrical Conductivity of Geopolymer Pastes}

In order to better assess the temperature impact of the AS on geopolymer pastes, electrical conductivity was performed (Figure 3). It is known that electrical conductivity depends on the ions' concentration in the solution. When the $10 \mathrm{M} \mathrm{NaOH}$ is diluted with water, the degree of dissociation increases, which causes an increase in electrical conductivity. In the case of a strong electrolyte with a decrease in concentration, the interaction of ions with each other is weakened, which increases the speed of their movement and therefore the conductivity of the solution [32]. By increasing the water $/ 10 \mathrm{M} \mathrm{NaOH}$ ratio in the AS used for the preparation of the geopolymer pastes, the electrical 
conductivity was increased. It is known that the dissolution process is influenced by temperature; the number of ions in a solution increases by increasing the temperature of the solution and the degree of dissociation increases since the bonds in the electrolyte molecules are activated [33]. As the bonds become more mobile, they are more easily ionized; as a result, the concentration of ions in the solution increases. The obtained data (Figure 3) show that the electrical conductivity of the geopolymer paste is significantly influenced by the temperature of the paste. The lowest electrical conductivity was seen in the geopolymer pastes with the lowest initial temperature $\left(5^{\circ} \mathrm{C}\right)$. With the increase in the water/ $10 \mathrm{M} \mathrm{NaOH}$ ratio (from 0.6 to 1.8), the ion content in the paste decreased by $30 \%$ and the electrical conductivity of the paste increased from 90 to $120 \mathrm{mS}$. Insignificant changes in electrical conductivity were detected for the pastes made by using the AS with the lowest water/10 $\mathrm{M} \mathrm{NaOH}$ ratio, with no significant effect from the initial temperature of the paste.

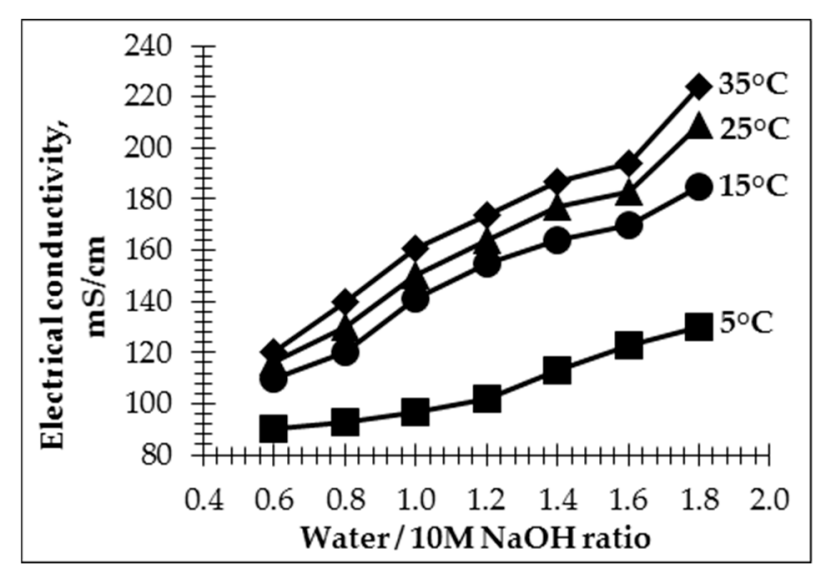

Figure 3. The electrical conductivity of geopolymer pastes affected by the water/10 $\mathrm{M} \mathrm{NaOH}$ ratio of activation solution used and the paste's initial temperature.

A noticeable increase in electrical conductivity (from $22 \%$ to $46 \%$ ) was observed by increasing the initial temperature of the geopolymer paste from $5{ }^{\circ} \mathrm{C}$ to $15^{\circ} \mathrm{C}$. The tendencies remained the same for all pastes across different initial temperatures: by increasing the water $/ 10 \mathrm{M} \mathrm{NaOH}$ ratio in the AS, the electrical conductivity increased. Further increasing the paste's initial temperature to $25^{\circ} \mathrm{C}$ and $35^{\circ} \mathrm{C}$ increased the electrical conductivity to $5.5-11 \%$ and $9-17.9 \%$, compared to the electrical conductivity of the pastes with an initial temperature of $15^{\circ} \mathrm{C}$. The largest increase in electrical conductivity was detected for pastes made with an AS containing a higher water/10 $\mathrm{M} \mathrm{NaOH}$ ratio. This means that the amount of water in a geopolymer paste plays an important role in increasing its electrical conductivity.

\subsection{Viscosity of Geopolymer Pastes}

Studying the dynamic viscosity of the geopolymer pastes (Figure 4) with activation solutions with differing water $10 \mathrm{M} \mathrm{NaOH}$ ratios showed that an increase of this ratio leads to a decrease in the viscosity of geopolymer pastes. The relation between electrical conductivity and viscosity can be seen. The higher viscosity of the paste leads to lower mobility of the ions and, therefore, lower conductivity [33]. The highest viscosity was observed for geopolymer pastes with an initial temperature of $5{ }^{\circ} \mathrm{C}$. The significant decrease of viscosity (approximately two times, from 350 to $170 \mathrm{mPa} \cdot \mathrm{s}$ ) was observed for pastes with a water/ $10 \mathrm{M} \mathrm{NaOH}$ ratio in the AS from 0.6 to 1.2, respectively. The same results are presented in several papers $[17,34,35]$ and it is concluded that viscosity is increased by increasing the concentration of $\mathrm{NaOH}$ in the activation solution. This is related to the higher $\mathrm{OH}-$ concentration in the AS and is confirmed by other researchers [36]. When the water/10 $\mathrm{M} \mathrm{NaOH}$ ratio in the AS is higher than 1.2, the decrease in the paste's viscosity is insignificant. 
By increasing the initial temperature of the paste, the mobility of ions and the electrical conductivity of the AS also increases [32], effecting an increase in the degree of dissociation in the solution followed by a decrease in the viscosity and the degree of ion hydration of the solution.

The viscosity of the geopolymer pastes was reduced by increasing the initial temperature of the pastes. As the water $/ 10 \mathrm{M} \mathrm{NaOH}$ ratio in the activation solution and initial temperature of the paste have an impact on the ion concentration and viscosity, those parameters can be used to control the workability of geopolymer pastes.

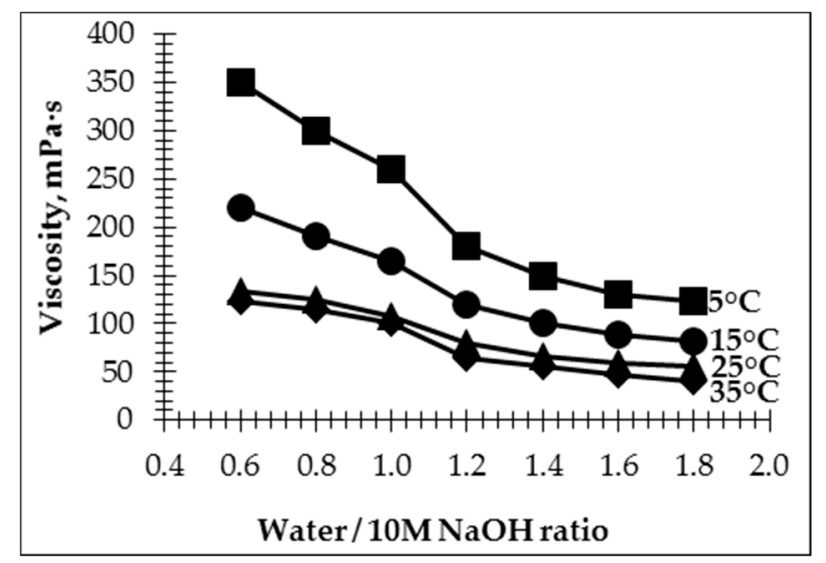

Figure 4. The viscosity of geopolymer pastes affected by the water/10 $\mathrm{M} \mathrm{NaOH}$ ratio of activation solution used and the paste's initial temperature.

\subsection{The Spread of Geopolymer Pastes}

The mini-slump test was performed immediately after the pastes were mixed (and at $10 \mathrm{~min}$ and $20 \mathrm{~min}$ ). It is known that the fluidity of fresh geopolymer pastes, tested by the mini-slump test, is closely related to the yield stress and plastic viscosity of the pastes [10,37]. An increase in the water $/ 10 \mathrm{M} \mathrm{NaOH}$ ratio in the AS causes an increase of spread diameter. This tendency was observed for all the studied geopolymer pastes regardless of the initial temperature of the paste. An increase in the paste's initial temperature also had an impact on the paste spread values.

This result is confirmed by other investigations $[38,39]$. It can be concluded that spread values depend on the electrical conductivity and viscosity of the pastes. The lowest spread diameter (10.4-16.0 mm depending on the water/10 M NaOH ratio) was observed in pastes with an initial temperature of $5^{\circ} \mathrm{C}$ (Figure $5 \mathrm{a}$ ). In the pastes with an initial temperature of $5^{\circ} \mathrm{C}$ and a higher water $/ 10 \mathrm{M}$ $\mathrm{NaOH}$ ratio in the AS, spread changes were noticeable; but in pastes with a lower water $/ 10 \mathrm{M} \mathrm{NaOH}$ ratio in the AS, the difference was small. After $10 \mathrm{~min}$ and $20 \mathrm{~min}$, the changes in paste spread (i.e., the decrease of spread values) became insignificant.

By increasing the initial temperature of the geopolymer paste to $15{ }^{\circ} \mathrm{C}$, a minor increase in spread diameter was observed (Figure $5 b$ ). The results obtained reflect the results demonstrated in Figures 3 and 4, where it can be seen that the electrical conductivity and viscosity for the mentioned pastes significantly increased by increasing the initial temperature of the paste to $15^{\circ} \mathrm{C}$. The spread changes are not noteworthy at $10 \mathrm{~min}$, but at $20 \mathrm{~min}$ the tendency for a slight decrease in spread value was observed.

A particularly significant spread increase was observed when the initial temperature was increased to $25^{\circ} \mathrm{C}$ and $35^{\circ} \mathrm{C}$ (Figure $5 \mathrm{c}, \mathrm{d}$ ). For the pastes with higher water/10 M NaOH ratios in the AS, the dilution process of the activation solution significantly affected the increase of electrical conductivity and viscosity (Figures 3 and 4) and had an influence on the paste spread diameter. For these pastes, spread diameter reached $16-20 \mathrm{~cm}$, which does not ensure proper workability of the paste. The same results were seen in studies where an increase in slump spread was observed when the amount of water in the mixture was increased $[10,40]$. 
A satisfactory spread diameter for sample preparation is $14 \mathrm{~cm}$. This was determined only for pastes M0.6, M0.8 and M1.0. It can be emphasized that geopolymer pastes with a lower concentration of alkali in the composition can have molding difficulties because of their high fluidity. There is a clear tendency that the spread diameter of geopolymer pastes decreases a little over time (10 $\mathrm{min}$ and $20 \mathrm{~min}$ after mixing the paste). This indicates that the formation of the primary gel structure occurs more intensively in pastes with a higher initial temperature $\left(25^{\circ} \mathrm{C}\right.$ and $\left.35^{\circ} \mathrm{C}\right)$ in the first $20 \mathrm{~min}$ after mixing, due to the higher electrical conductivity of the pastes [25].
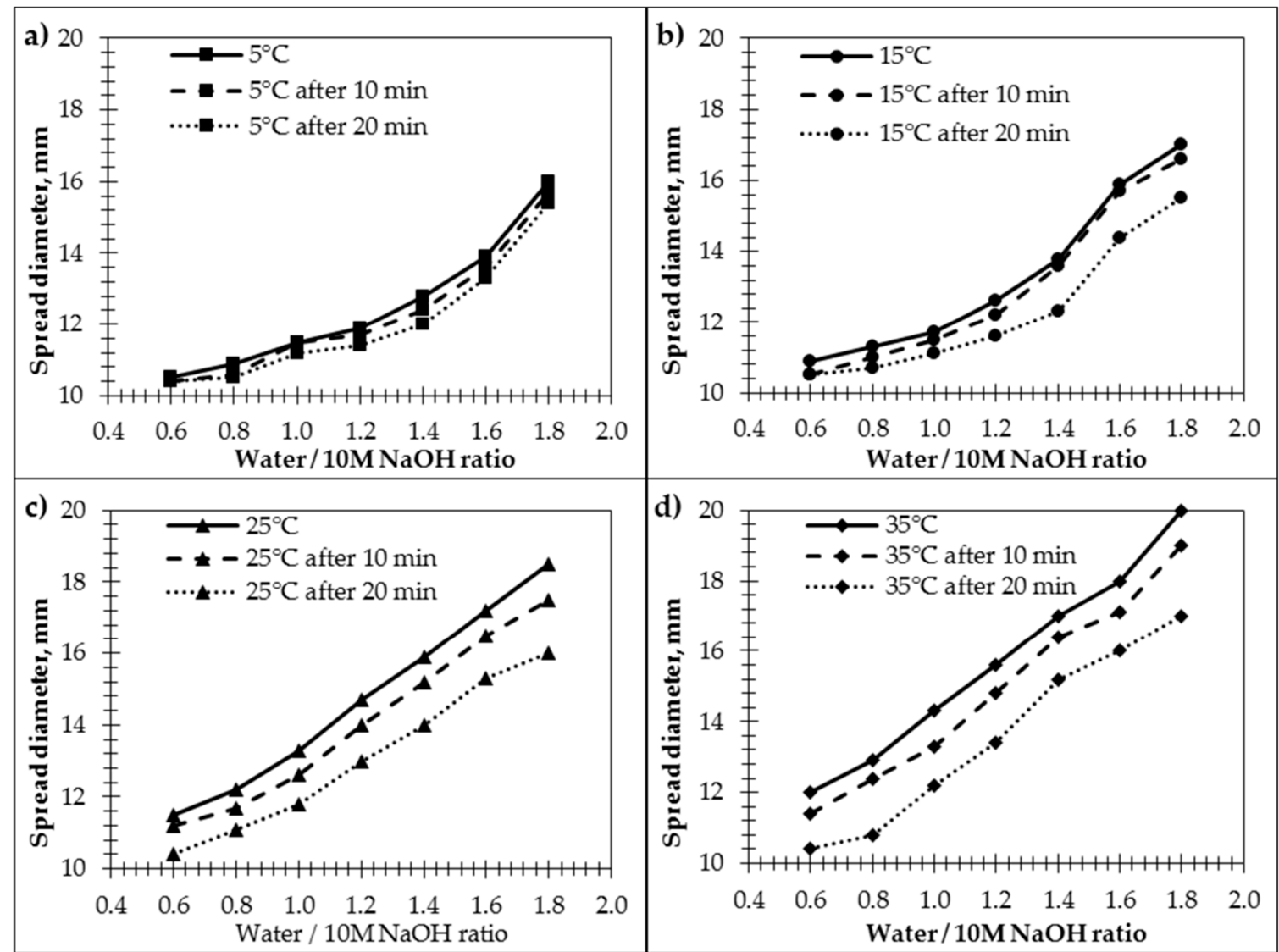

Figure 5. Spread diameter of the geopolymer paste depending on the water/10 $\mathrm{M} \mathrm{NaOH}$ ratio in the alkaline solution (AS) immediately and at $10 \mathrm{~min}$ and $20 \mathrm{~min}$ after mixing: (a) initial geopolymer paste temperature of $5{ }^{\circ} \mathrm{C}$; (b) initial geopolymer paste temperature of $15^{\circ} \mathrm{C}$; (c) initial geopolymer paste temperature of $25^{\circ} \mathrm{C}$; (d) initial geopolymer paste temperature of $35^{\circ} \mathrm{C}$.

It can be concluded that satisfactory fluidity is observed in pastes with a higher water/10 $\mathrm{M}$ $\mathrm{NaOH}$ ratio in the activation solution and with lower initial temperatures $\left(5^{\circ} \mathrm{C}\right.$ and $\left.15^{\circ} \mathrm{C}\right)$; but with a higher initial paste temperature $\left(25^{\circ} \mathrm{C}\right.$ and $\left.35^{\circ} \mathrm{C}\right)$, satisfactory fluidity is seen in pastes with a lower water $/ 10 \mathrm{M} \mathrm{NaOH}$ ratio in the activation solution.

\subsection{The Density of Geopolymers Made of Pastes with Different Initial Temperatures}

To determine the physical-mechanical properties, the three series of specimens were prepared with an activation solution containing different water $/ 10 \mathrm{M} \mathrm{NaOH}$ ratios. The aim of the research was to evaluate the impact of the paste's initial temperature and the amount of extra water in the activation solution on its physical and mechanical properties. The specimens made from the paste with an initial temperature of $5{ }^{\circ} \mathrm{C}$ were marked as M0.6-5, M1.0-5 and M1.4-5; those made from the paste with an initial temperature of $15^{\circ} \mathrm{C}$ were marked as M0.6-15, M1.0-15 and M1.4-15; and those made from the 
paste with an initial temperature of $35^{\circ} \mathrm{C}$ were marked as M0.6-35, M1.0-35 and M1.4-35. Specimens were cured at $80^{\circ} \mathrm{C}$ and kept at standard room temperature for 7,28 and 56 days.

The curing process has an obvious effect on the structural and mechanical properties of geopolymer specimens $[41,42]$. It is noted in several studies $[16,28,43]$ that curing at a temperature between $40{ }^{\circ} \mathrm{C}$ and $80^{\circ} \mathrm{C}$ for 4 to $48 \mathrm{~h}$ is one of the important aspects for the synthesis of geopolymer materials.

Specimens prepared from the pastes with initial temperatures between $15^{\circ} \mathrm{C}$ and $35^{\circ} \mathrm{C}$ were cured at an elevated temperature for two hours. They were then demolded and their density was measured (Figure 6). Previously prepared samples made with an initial temperature of $5{ }^{\circ} \mathrm{C}$ were not enough solid for demolding. The lower water $/ 10 \mathrm{M} \mathrm{NaOH}$ ratio in the activation solution caused higher sample density (Figure 6) throughout the heat treatment period $(2 \mathrm{~h})$. Densities varied from $1844 \mathrm{~kg} / \mathrm{m}^{3}$ to $1670 \mathrm{~kg} / \mathrm{m}^{3}$ for samples prepared from the paste with an initial temperature of $15^{\circ} \mathrm{C}$. However, for samples prepared from the paste with an initial temperature of $35^{\circ} \mathrm{C}$, the density was higher and varied from $1875 \mathrm{~kg} / \mathrm{m}^{3}$ to $1730 \mathrm{~kg} / \mathrm{m}^{3}$.

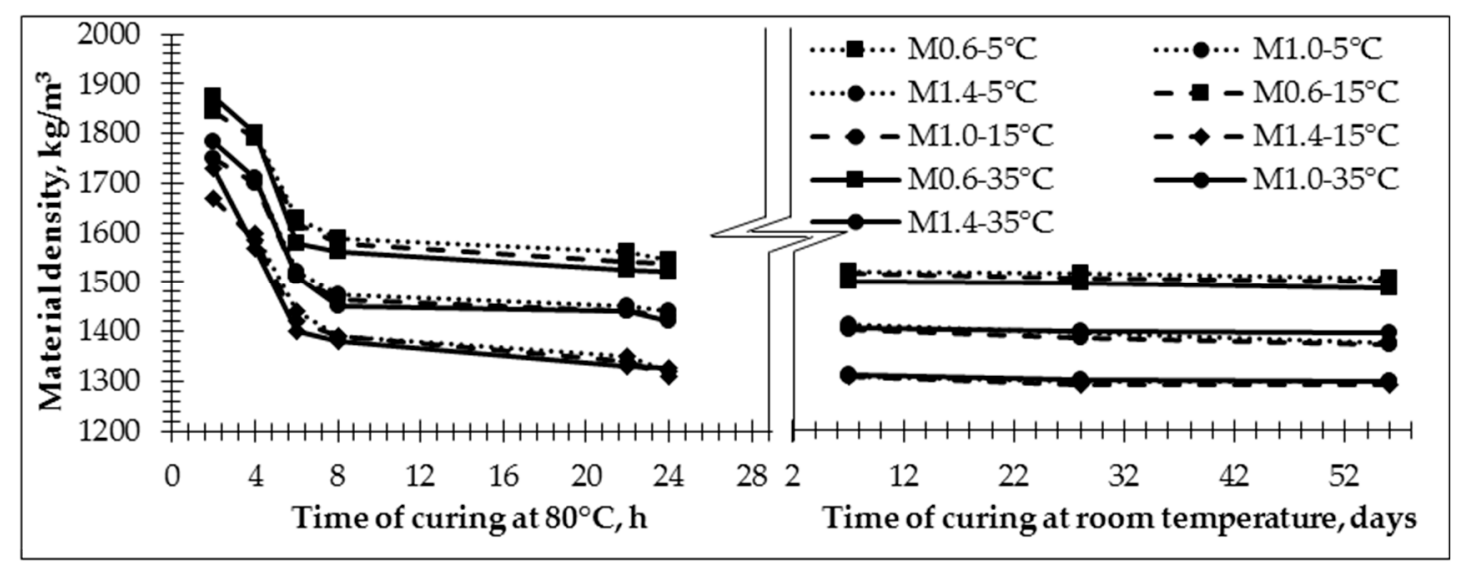

Figure 6. The density of geopolymer specimens prepared from pastes with initial temperatures of $5{ }^{\circ} \mathrm{C}$, $15^{\circ} \mathrm{C}$ and $35^{\circ} \mathrm{C}$ during curing at elevated temperature and room temperature.

The density of samples prepared from the paste with an initial temperature of $5^{\circ} \mathrm{C}$ and cured for four hours at an elevated temperature $\left(80^{\circ} \mathrm{C}\right)$ varied from $1800 \mathrm{~kg} / \mathrm{m}^{3}$ to $1598 \mathrm{~kg} / \mathrm{m}^{3}$. It can be seen that there is not a significant change in the density of the samples with the same composition but different initial paste temperatures $\left(5^{\circ} \mathrm{C}, 15^{\circ} \mathrm{C}\right.$ and $\left.35^{\circ} \mathrm{C}\right)$. As shown by other researchers [44], the density of geopolymer specimens decreases when extra water is used for specimen production because water is released during hydrolysis, geopolymerisation and condensation. Significant decreases in density were observed for all specimens after six hours of exposure to elevated temperatures. The density of the specimens prepared from the paste with an initial temperature of $5{ }^{\circ} \mathrm{C}$ decreased by $9.6-11 \%$ compared to the density of the specimens prepared in same manner but cured for a shorter period of time (four hours) at elevated temperatures. Density decreased by $12.2-14.9 \%$, and by $15.7-19.2 \%$, for specimens prepared from pastes with initial temperatures of $15^{\circ} \mathrm{C}$ and $35^{\circ} \mathrm{C}$, respectively, compared to the density of the specimens made in the same manner but only cured for two hours at the elevated temperature. Further retention of the samples for 22-24 h resulted in a significant decrease in density for all samples. The largest density decrease was detected for the samples made with an activation solution with a higher water $/ 10 \mathrm{M} \mathrm{NaOH}$ ratio. The density decreased up to $17.5 \%, 21.6 \%$ and $23.4 \%$ for samples M1.4-5, M1.4-15 and M1.4-35, respectively. For samples with a lower water/10 M NaOH ratio in the activation solution, density decreased $14.3 \%, 16.6 \%$ and $18.9 \%$.

After the extended curing process (7, 28 and 56 days) at room temperature, regardless of the paste's initial temperature, the density of the specimens mostly decreased during the first seven days (1.7\%). After 56 days, the density of samples decreased $0.5-0.6 \%$. 
This research shows that the amount of extra water (the water/10 $\mathrm{M} \mathrm{NaOH}$ ratio) in the activation solution affects the density of samples. The same tendencies are shown in the reports of other researchers [38].

\subsection{UPV of Geopolymer Specimens Made from Pastes with Different Initial Temperatures}

The structural evolution process of samples depends on the initial paste temperature and the water/10 $\mathrm{M} \mathrm{NaOH}$ ratio in the activation solution (Figure 7). By decreasing the water/10 $\mathrm{M} \mathrm{NaOH}$ ratio in the activation solution, the UPV values of the samples increased. The UPV values for samples of the same composition prepared at $15^{\circ} \mathrm{C}$ and cured for two hours at $80^{\circ} \mathrm{C}$ was $1.5-1.8$ times lower than for the samples prepared at $35^{\circ} \mathrm{C}$. This is apparently influenced by the higher electrical conductivity, which accelerates geopolymerisation reactions. After four to six hours curing at the elevated temperature, there was a marked change in the structure of the samples made using a lower water/10 $\mathrm{M} \mathrm{NaOH}$ ratio in the AS. This is related to the decreased density: the UPV increased three times and reached $1359 \mathrm{~m} / \mathrm{s}$ for M0.6-35, $880 \mathrm{~m} / \mathrm{s}$ for M0.6-15, and $720 \mathrm{~m} / \mathrm{s}$ for M0.6-5. For the samples with a higher water/10 M NaOH ratio (0.14) in the AS, the UPV value was significantly lower: $600 \mathrm{~m} / \mathrm{s}$ (M1.4-5), $430 \mathrm{~m} / \mathrm{s}$ (M1.4-35), and $330 \mathrm{~m} / \mathrm{s}$ (M1.4-15).

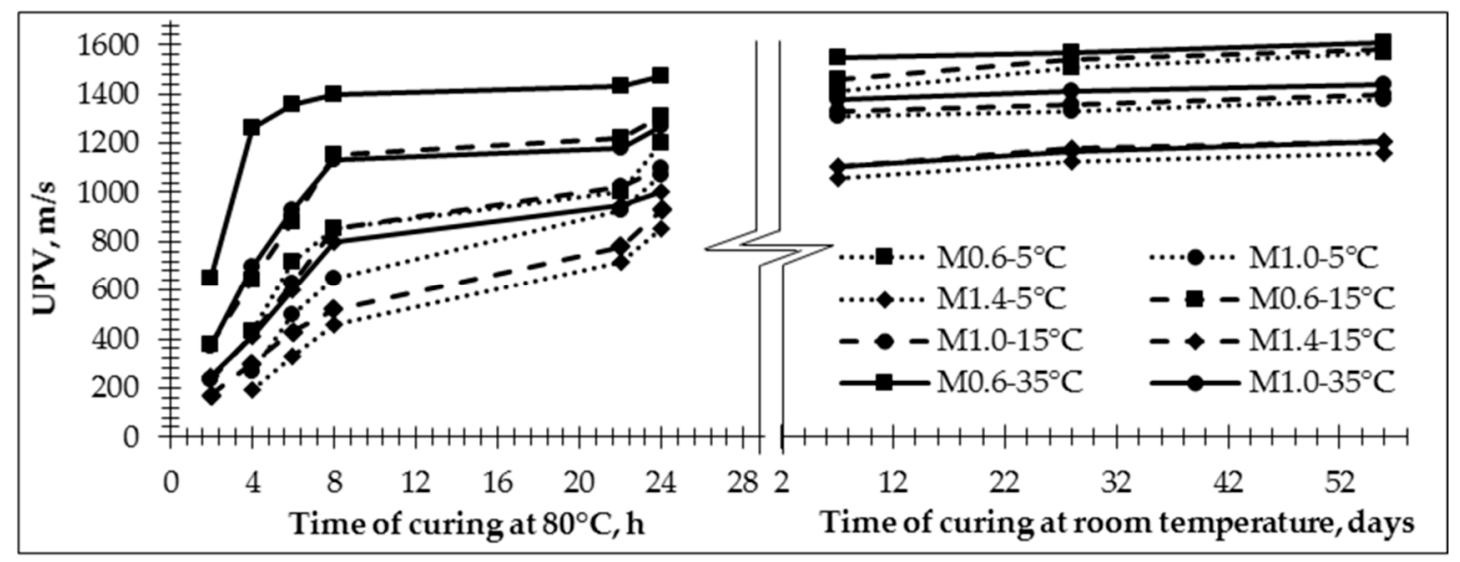

Figure 7. The ultrasonic pulse velocity (UPV) of geopolymer specimens prepared from the pastes with initial temperatures of $5{ }^{\circ} \mathrm{C}, 15^{\circ} \mathrm{C}$ and $35^{\circ} \mathrm{C}$ and cured at elevated and room temperatures.

The structural formation of the samples prepared from paste with an initial temperature of $5{ }^{\circ} \mathrm{C}$ was prolonged, taking $24 \mathrm{~h}$. The same tendency was observed for the compositions prepared using paste with an initial temperature of $15^{\circ} \mathrm{C}$. The structural formation depends on the water/10 $\mathrm{M} \mathrm{NaOH}$ ratio in the activation solution and takes four to six hours. The UPV values after the samples had hardened for $24 \mathrm{~h}$ at an elevated temperature $\left(80^{\circ} \mathrm{C}\right)$ does not depend on the composition of the specimens, but mainly depends on the initial temperature of the paste used. The UPV for samples prepared from paste with an initial temperature of $5{ }^{\circ} \mathrm{C}$ was lower by $11 \%$ and $19 \%$ compared with the UPV of the same samples prepared from paste with temperatures of $15^{\circ} \mathrm{C}$ and $35^{\circ} \mathrm{C}$, respectively. According to previously published research $[29,44-46]$, the amount of water in the activation solution is the dominant factor affecting the density and open porosity of geopolymers after curing at elevated and room temperatures. It is possible to conclude that not only the increased water content in the activation solution but also the low initial temperature of the paste negatively impacts on structural formation, prolonging structural formation and resulting in lower UPV values. Higher paste temperatures and a lower water/ $10 \mathrm{M} \mathrm{NaOH}$ ratio in the activation solution led to the acceleration of structural formation and can significantly reduce the curing time of specimens.

The water $/ 10 \mathrm{M} \mathrm{NaOH}$ ratio in the activation solution had a significant impact on the hardening process of the geopolymers over time: a lower water/10 $\mathrm{M} \mathrm{NaOH}$ ratio in the AS promoted a higher UPV value for the samples after 7, 28 and 56 days of curing at room temperature. The UPV mostly 
increased during the first seven days: up $14.3-16.7 \%$ for the samples prepared from paste with an initial temperature of $5^{\circ} \mathrm{C}$; up $9.6-16.6 \%$ for samples prepared from paste with an initial temperature of $15^{\circ} \mathrm{C}$; and up $4.2-10.1 \%$ for samples prepared from paste with an initial temperature of $35^{\circ} \mathrm{C}$. The same tendencies were observed for samples after curing for 28 and 56 days: the UPV for the samples increased 3-8\%. The higher the initial temperature of the paste, the lower the UPV increment for samples cured for between seven and 56 days.

\subsection{Porosity and Pore Size Distribution of Geopolymers}

Density and UPV tests were confirmed by an apparent porosity test of the samples after curing (Figure 8). It was determined that samples with a lower water $/ 10 \mathrm{M} \mathrm{NaOH}$ ratio (0.6 respectively) in the activation solution presented a higher open porosity of 25.0\% (M0.6-5), 29.3\% (M0.6-15) and 34.8\% (M0.6-35) compared with other specimens made using activation solutions with higher water/10 M $\mathrm{NaOH}$ ratio. A lower water/10 $\mathrm{M} \mathrm{NaOH}$ ratio in the activation solution resulted in higher open porosity. According to previous research [29], the amount of water is the dominant factor affecting the density and the open porosity of geopolymers after curing at elevated and room temperatures. The UPV values, which are comparably lower for the samples prepared with a higher water/10 $\mathrm{M} \mathrm{NaOH}$ ratio in the activation solution, are linked to a higher open porosity of the hardened samples.

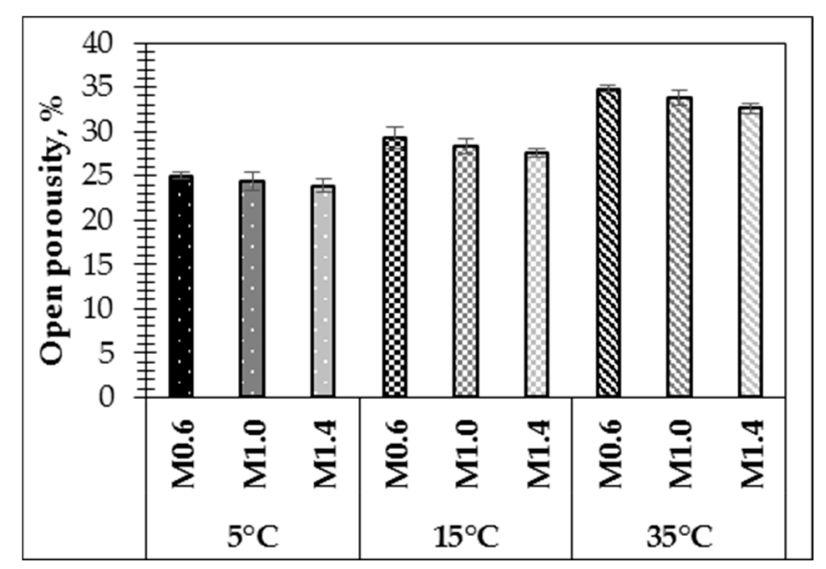

Figure 8. Open porosity changes of the studied geopolymer.

According to mercury porosimeter results (Figure 9a,b), specimen M0.6-5 mainly has pores within three intervals of diameter: from $0.01 \mu \mathrm{m}$ to $0.1 \mu \mathrm{m}$, from $0.3 \mu \mathrm{m}$ to $0.8 \mu \mathrm{m}$ and from $1.0 \mu \mathrm{m}$ to $4.0 \mu \mathrm{m}$. The total pore volume of M0.6-5 reaches $0.2798 \mathrm{~cm}^{3} / \mathrm{g}$. On the contrary, specimen M0.6-35, made of paste with a higher initial temperature of $35^{\circ} \mathrm{C}$, has only two intervals of diameter for its dominant pores: from $0.01 \mu \mathrm{m}$ to $0.1 \mu \mathrm{m}$ and from $0.3 \mu \mathrm{m}$ to $0.5 \mu \mathrm{m}$. The total pore volume of M0.6-35 reaches $0.2670 \mathrm{~cm}^{3} / \mathrm{g}$. This means that by increasing the initial paste temperature, the porosity of the geopolymer specimens decreases and pores with sizes larger than $1 \mu \mathrm{m}$ disappear. The pore size becomes smaller.

The analysis showed that the pore size distribution for the M1.4-5 sample is different (Figure 10a). The range of sizes of the dominant pores increases in two diameter intervals, from $0.05 \mu \mathrm{m}$ to $0.5 \mu \mathrm{m}$ and from $0.8 \mu \mathrm{m}$ to $8 \mu \mathrm{m}$. The total pore volume of M1.4-5 reaches $0.381 \mathrm{~cm}^{3} / \mathrm{g}$. This means that the higher water $10 \mathrm{M} \mathrm{NaOH}$ ratio in the activation solution results in higher porosity with a larger size of dominant pores compared with the specimens made from paste produced by an activation solution with less water in it. As observed earlier, a higher initial temperature of the paste used for sample preparation promotes the formation of smaller pores and the total porosity is comparably smaller (the total pore volume of M1.4-35 reaches $0.358 \mathrm{~cm}^{3} / \mathrm{g}$ ). 

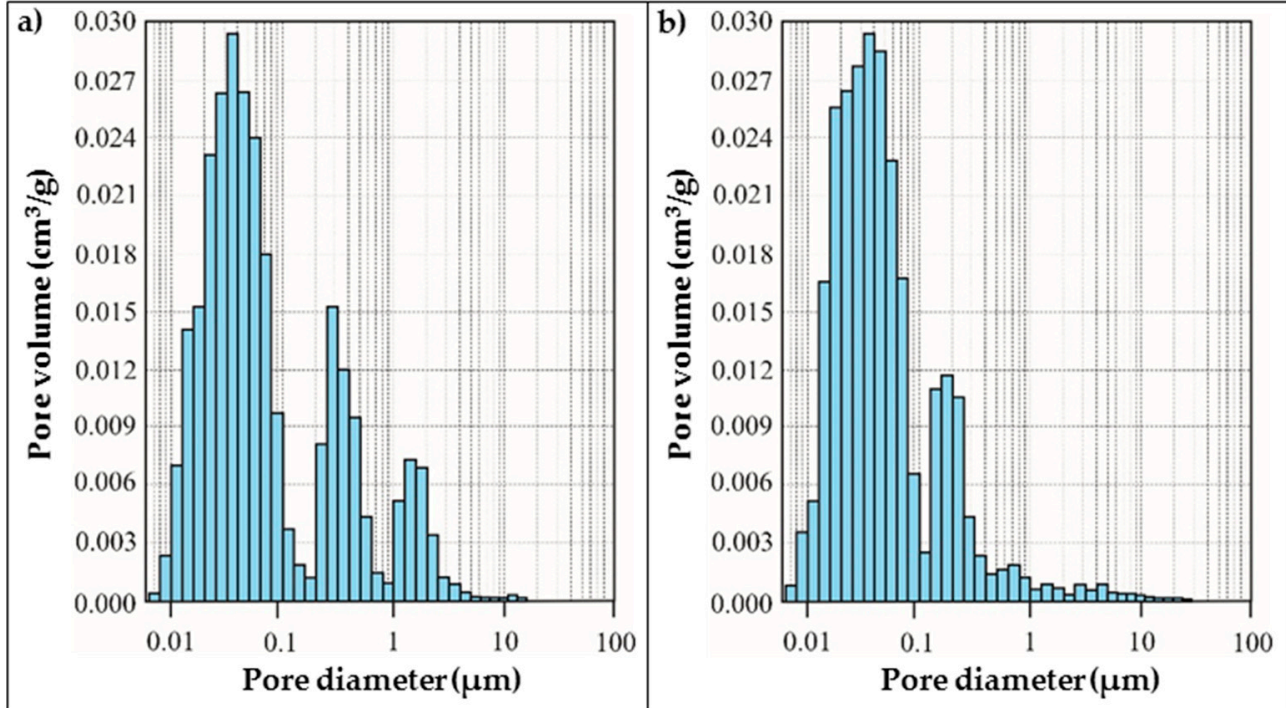

Figure 9. Pore size distribution: (a) M0.6-5; (b) M0.6-35.
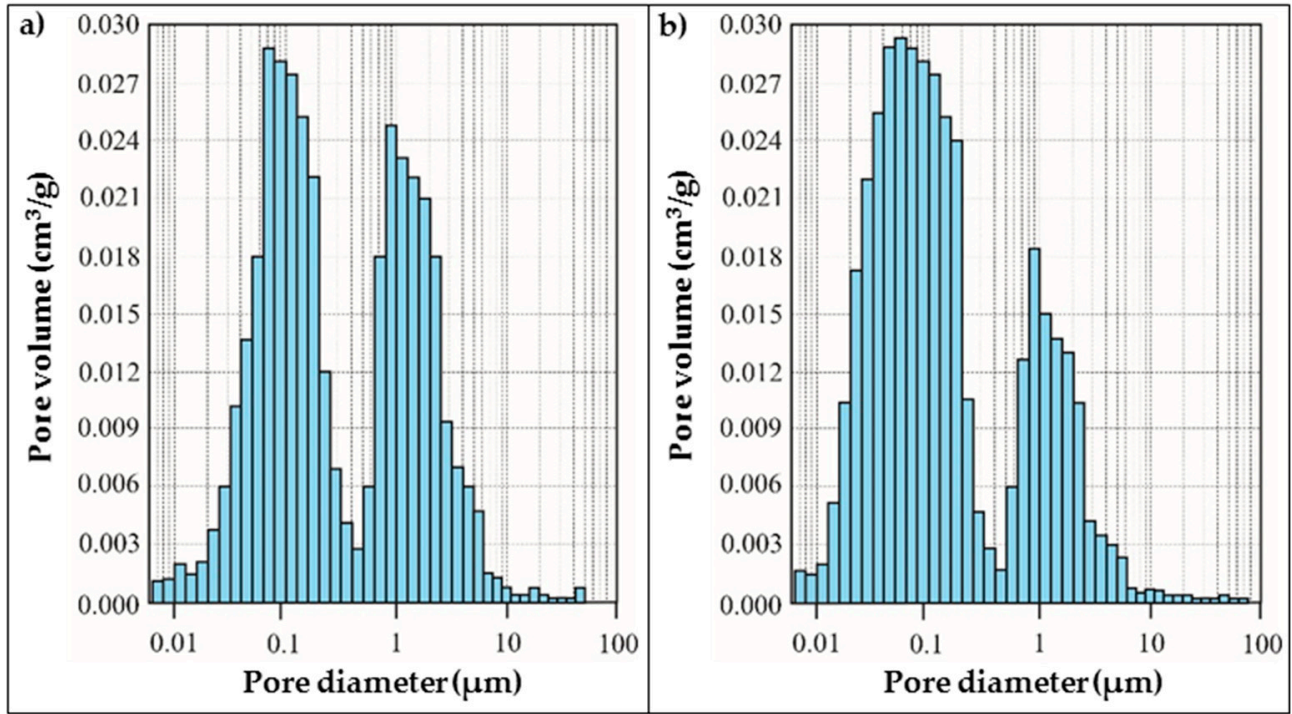

Figure 10. Pore size distribution: (a) M1.4-5; (b) M1.4-35.

It can be seen that a lower water $/ 10 \mathrm{M} \mathrm{NaOH}$ ratio in the activation solution results in the formation of smaller pores and the total porosity decreases compared with specimens made with an activation solution with a higher water $/ 10 \mathrm{M} \mathrm{NaOH}$ ratio.

The initial temperature of the paste effects pore formation as well. A higher initial temperature of the paste initiates the formation of small sized pores and the total pore volume is smaller, which shows the relationship between the viscosity of the paste and the dominant size of the pores. Larger pore size and pore volume appear in the specimens made from paste with lower initial temperatures, apparently due to the lower viscosity of the paste [19].

\subsection{Compressive Strength of Geopolymers Made from Pastes with Different Initial Temperatures}

Mechanical properties were determined for the specimens after curing them at $80^{\circ} \mathrm{C}$ for $24 \mathrm{~h}$ and extended curing at room temperature for 7, 28 and 56 days. It was detected that a lower water/10 M $\mathrm{NaOH}$ ratio in the AS and a higher temperature of the paste used for the geopolymer preparations led to a higher compressive strength after $24 \mathrm{~h}$ of curing (Figure 11). Such a tendency is also described by other researchers [47]. By increasing the water/10 $\mathrm{M} \mathrm{NaOH}$ ratio in the AS used for the paste 
preparation, the compressive strength of the geopolymers decreased up to three times. Similar results are noted in several other studies $[12,35,48,49]$, where it was found that the compressive strength of the geopolymer increased with the increased alkali concentration.

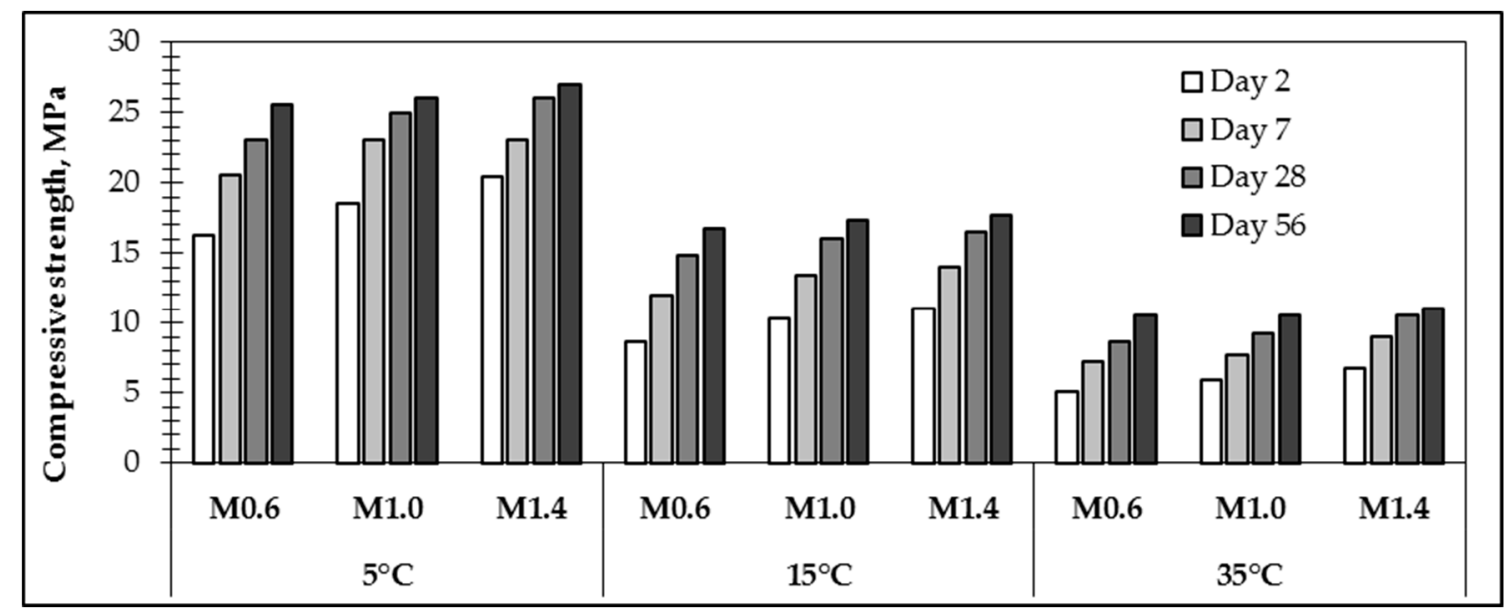

Figure 11. Compressive strength changes over time in geopolymers prepared at $5^{\circ} \mathrm{C}, 15^{\circ} \mathrm{C}$ and $35{ }^{\circ} \mathrm{C}$.

The compressive strength of the samples with different water/10 $\mathrm{M} \mathrm{NaOH}$ ratios in the AS prepared from paste with an initial temperature $35^{\circ} \mathrm{C}$ was the lowest: $16.3 \mathrm{MPa}(\mathrm{M} 0.6-35), 8.60 \mathrm{MPa}$ (M1.0-35) and 5.10 MPa (M1.4-35). The compressive strength of the same samples prepared at $15^{\circ} \mathrm{C}$ was, respectively, $12.1 \%, 15.4 \%$ and $15.9 \%$ higher than in the samples prepared at $35^{\circ} \mathrm{C}$. The compressive strength of the same samples prepared at $5{ }^{\circ} \mathrm{C}$ was, respectively, $9.3 \%, 6.4 \%$ and $11.9 \%$ higher than in the samples prepared at $15^{\circ} \mathrm{C}$. The mechanical properties obviously correlate with porosity and the results obtained from the research on structural development, which shows that a higher initial temperature of the paste used for sample preparation visibly accelerates structural formation, reduces porosity and increases compressive strength.

During the whole curing period of up to 56 days, the compressive strength of the samples prepared from paste with an initial temperature of $5^{\circ} \mathrm{C}$ increased 1.65-2 times compared with samples prepared from paste with an initial temperature of $15^{\circ} \mathrm{C}$, and samples prepared from pastes with higher initial temperatures $\left(35^{\circ} \mathrm{C}\right)$ increased 1.3-1.7 times compared with samples prepared from paste with an initial temperature of $15^{\circ} \mathrm{C}$.

Mostly, the compressive strength of samples increased during the first seven days. It is detected that the compressive strength growth rates were higher for compositions with a higher water/10 M $\mathrm{NaOH}$ ratio in the AS and prepared from paste with an initial temperature of $5{ }^{\circ} \mathrm{C}$. Compressive strength increases become noticeably slower after 28 days of curing.

For samples cured for 56 days, the compressive strength growth rates were significantly lower by $4-8 \%$. The same results are observed by Nurruddin et al. [50], where it is pointed out that the change in strength with an extended curing time at room temperature for samples initially cured in the oven at an elevated temperature is not significant. The strength values of samples prepared at different temperatures with the same water $/ 10 \mathrm{M} \mathrm{NaOH}$ ratio in the AS practically levelled off.

\subsection{X-ray Diffraction Analysis of Geopolymer Pastes with Different Initial Temperatures}

The XRD patterns (Figure 12) show that all the samples have the same crystalline phases: quartz $\left(\mathrm{SiO}_{2}\right)$, which comes from raw metakaolin; hydroxy sodalite $\left(1.08 \mathrm{Na}_{2} \mathrm{O} \cdot \mathrm{Al}_{2} \mathrm{O}_{3} \cdot 1.68 \mathrm{SiO}_{2} \cdot 1.8 \mathrm{H}_{2} \mathrm{O}\right.$; sodalite group zeolites); and geopolymer gel, which is formed during the metakaolin geopolymerisation process [15]. The shift to higher degrees of halo at $2 \Theta=10-30^{\circ}$ that shows in the amorphous phase in raw materials is characterized as geopolymer gel formation during the alkali activation process $[27,39,51,52]$. 
The lowest water/10 $\mathrm{M} \mathrm{NaOH}$ ratio in the AS used for geopolymer preparation led to a higher geopolymerisation reaction rate and crystallization of the hydroxy sodalite crystallization. The diffraction peak intensities of hydroxy sodalite for samples M0.6-5 and M0.6-35 were significantly higher than for M1.4-5 and M1.4-35. In addition, significantly fewer quartz diffraction peaks were seen in the XRD patterns in the M0.6-5 and M0.6-35 samples than in the M1.4-5 and M1.4-35 samples. The hydroxy sodalite diffraction peaks intensity was higher for the samples prepared from the paste with an initial temperature of $35^{\circ} \mathrm{C}$ compared with samples prepared from the paste with a temperature of $5{ }^{\circ} \mathrm{C}$. These studies confirm the compressive strength test results and reveal that a lower water/10 M $\mathrm{NaOH}$ ratio in the AS and a higher paste temperature for geopolymer preparation can significantly affect the mineral formation and, as a consequence, affect the physical and mechanical properties of the samples.

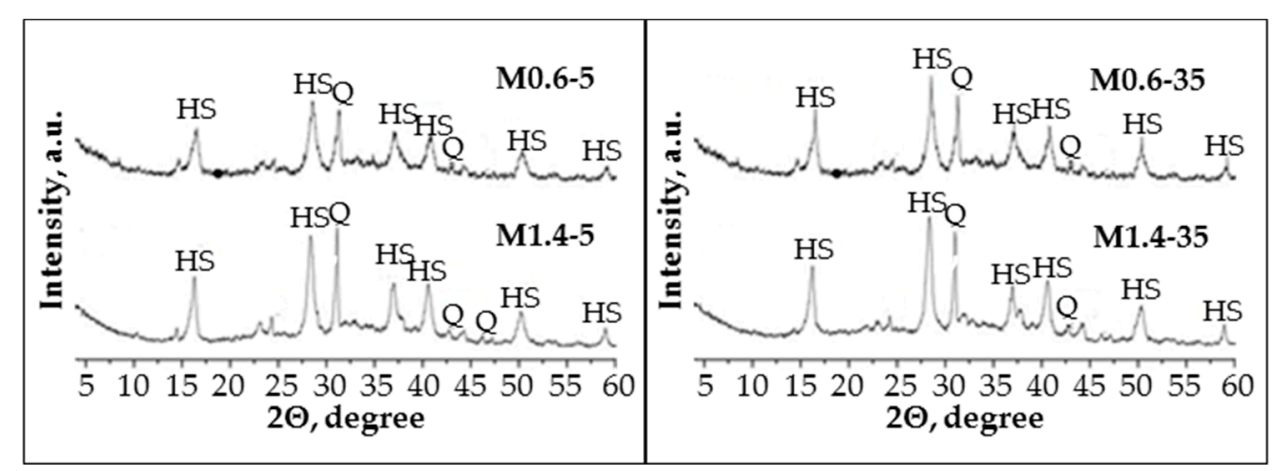

Figure 12. X-ray diffraction (XRD) analysis of geopolymer pastes.

\section{Conclusions}

The acceptance of alkali-activated materials by the construction industry is needed at industrial scale. To do so, it is important to determine key parameters affecting workability and fluidity of the fresh paste of geopolymers. It is especially important for construction sites where temperature can rapidly change during daytime or to be extremely different depending on the time of year. Initial temperatures of the geopolymer paste and extra water addition to the composition can change workability of the fresh mix, which will result in different properties of the hardened materials compared with planned ones.

The paste's initial temperature and extra water in activation solution, reflected in an increase in the water/10 $\mathrm{M} \mathrm{NaOH}$ ratio, significantly affected the electrical conductivity, viscosity and spread values of geopolymer pastes and, therefore, the structural development, density, porosity and compressive strength of the samples after curing.

Increasing the initial temperature of the paste from $5{ }^{\circ} \mathrm{C}$ to $35^{\circ} \mathrm{C}$ led to an increase in the paste's electrical conductivity and spread values of up to $33.0 \%, 3.1 \%$ and $14.0 \%$ (for pastes with a water $10 \mathrm{M}$ $\mathrm{NaOH}$ ratio of 0.6 ) and up to $73.0 \%, 4.6 \%$ and $28.0 \%$ (for pastes with a high water $/ 10 \mathrm{M} \mathrm{NaOH}$ ratio of 1.4). On the contrary, increasing the initial temperature of the pastes from $5{ }^{\circ} \mathrm{C}$ to $35^{\circ} \mathrm{C}$ caused a 2.6-2.8-fold decrease in viscosity for pastes with a low water $/ 10 \mathrm{M} \mathrm{NaOH}$ ratio (0.6) and a three-fold decrease for pastes with high water/10 $\mathrm{M} \mathrm{NaOH}$ ratios (1.4). The fluidity of pastes varied according to the initial paste temperature.

The formation and compaction of the geopolymer structure is accelerated by increasing the initial temperature of the paste and decreasing the extra water in the activation solution (decreasing the ratio of water $10 \mathrm{M} \mathrm{NaOH}$ ). This is confirmed by the UPV measurements: the highest UPV values were detected for the specimens made using an alkali activation solution with a lower water $/ 10 \mathrm{M}$ $\mathrm{NaOH}$ ratio (0.6), meaning an accelerated formation of structure during the curing process compared to other compositions. The basic formation of the structure for the samples with a lower water $10 \mathrm{M}$ $\mathrm{NaOH}$ ratio (0.6) in the activation solution with initial paste temperatures of $35^{\circ} \mathrm{C}, 15^{\circ} \mathrm{C}$ and $5{ }^{\circ} \mathrm{C}$ occurred during the first four, eight and twenty-four hours. The structure formation was delayed until 
$22-24 \mathrm{~h}$ for samples with the highest water/10 $\mathrm{M} \mathrm{NaOH}$ ratios (1.4) in the activation solution. The UPV measurements also depended on the water $10 \mathrm{M} \mathrm{NaOH}$ ratio of the activation solution used for geopolymers: a lower water/10 $\mathrm{M} \mathrm{NaOH}$ ratio (0.6) of the activation solution led to an increase in the UPV values (8-17\%) for the samples after seven to fifty-six days of curing. Increases to the initial temperatures of the pastes used to prepare the samples led to the UPV increment becoming slower for the samples during their curing period.

Decreasing the amount of water in the activation solution led to a higher density (from $1510 \mathrm{~kg} / \mathrm{m}^{3}$ to $1530 \mathrm{~kg} / \mathrm{m}^{3}$ ), three times the compressive strength (from 5.1-6.7 MPa to 16.3-20.4 MPa), lower apparent porosity (from $36.6-37.8 \%$ to $26.9-28.0 \%$ ) and a predominance of pores with a smaller diameter (from $0.02-0.3 \mu \mathrm{m}$ to $0.007-0.06 \mu \mathrm{m}$ ) in the samples after curing at $80^{\circ} \mathrm{C}$. The influence of paste temperature appears in the following sequence: after curing, the compressive strength of the samples prepared from paste with a temperature of $5^{\circ} \mathrm{C}$ was $12.1-15.9 \%$, which is lower than those of the corresponding compositions manufactured from pastes with an initial temperature of $15^{\circ} \mathrm{C}$ or $35{ }^{\circ} \mathrm{C}(20.0-23.9 \%$ lower). The apparent porosity of the samples prepared from paste with an initial temperature of $5{ }^{\circ} \mathrm{C}$ was $2.1-3.1 \%$, which is higher than those of the corresponding compositions prepared from the paste at $15{ }^{\circ} \mathrm{C}$ and $3.9-5.8 \%$ higher than those of the corresponding compositions manufactured by using paste at $35^{\circ} \mathrm{C}$.

During the whole curing period of up to 56 days, the compressive strength of the samples prepared from paste with an initial temperature of $5^{\circ} \mathrm{C}$ increased more than $1.65-2$ times; for samples prepared from pastes with higher temperatures $\left(15^{\circ} \mathrm{C}\right.$ and $\left.35^{\circ} \mathrm{C}\right)$, the increase was $1.3-1.7$ times. After 56 days of curing, the strength and density of the samples prepared at different temperatures with the same water $/ 10 \mathrm{M} \mathrm{NaOH}$ ratio in the activation solution, had practically levelled off.

The XRD confirms the compressive strength test results and reveals that a lower water/10 $\mathrm{M}$ $\mathrm{NaOH}$ ratio in the activation solution and a higher initial paste temperature leads to a more intensive geopolymerisation reaction and formation of the reaction by-product, hydroxy sodalite.

Author Contributions: Conceptualization, L.V. and I.P.; methodology, I.P.; investigation, L.V., I.P. and J.P.; resources, I.P.; data curation, L.V.; writing-original draft preparation, L.V and I.P.; writing—review and editing, L.V., I.P., J.P. and D.B.; visualization, L.V. and J.P.; supervision, D.B.; funding acquisition, D.B. All authors have read and agreed to the published version of the manuscript.

Funding: This research was funded by the European Regional Development Fund project, "A New Concept for Low-Energy Eco-Friendly House", Grant Agreement No. 1.1.1.1/19/A/017.

Conflicts of Interest: The authors declare no conflict of interest.

\section{References}

1. Chi, M.; Huang, R. Binding mechanism and properties of alkali-activated fly ash/slag mortars. Constr. Build. Mater. 2013, 40, 291-298. [CrossRef]

2. Duxson, P.; Lukey, G.C.; Van Deventer, J.S. The thermal evolution of metakaolin geopolymers: Part 2-Phase stability and structural development. J. Non-Cryst. Solids 2007, 353, 2186-2200. [CrossRef]

3. Favier, A.; Habert, G.; De Lacaillerie, J.D.; Roussel, N. Mechanical properties and compositional heterogeneities of fresh geopolymer pastes. Cem. Concr. Res. 2013, 48, 9-16. [CrossRef]

4. Görhan, G.; Aslaner, R.; Şinik, O. The effect of curing on the properties of metakaolin and fly ash-based geopolymer paste. Compos. Part B: Eng. 2016, 97, 329-335. [CrossRef]

5. Güllü, H.; Nematollahi, B.; Al-Ezzi, K.M.; Gülsan, M.E. On the rheology of using geopolymer for grouting: A comparative study with cement-based grout included fly ash and cold bonded fly ash. Constr. Build. Mater. 2019, 196, 594-610. [CrossRef]

6. Habert, G.; De Lacaillerie, J.D.; Roussel, N. An environmental evaluation of geopolymer based concrete production: Reviewing current research trends. J. Clean. Prod. 2011, 19, 1229-1238. [CrossRef]

7. Jiménez, A.F.; Garcia-Lodeiro, I.; Palomo, A. Development of New Cementitious Caterials by Alkaline Activating Industrial by-Products. In IOP Conference Series: Materials Science and Engineering; IOP Publishing: Briston, England, 2015; Volume 96, p. 012005. 
8. Hou, L.; Li, J.; Lu, Z.-Y. Effect of $\mathrm{Na} / \mathrm{Al}$ on formation, structures and properties of metakaolin based Na-geopolymer. Constr. Build. Mater. 2019, 226, 250-258. [CrossRef]

9. Lee, S.; Van Riessen, A.; Chon, C.-M. Benefits of Sealed-Curing on Compressive Strength of Fly Ash-Based Geopolymers. Materials 2016, 9, 598. [CrossRef]

10. Ishwarya, G.; Singh, B.; Deshwal, S.; Bhattacharyya, S. Effect of sodium carbonate/sodium silicate activator on the rheology, geopolymerization and strength of fly ash/slag geopolymer pastes. Cem. Concr. Compos. 2019, 97, 226-238. [CrossRef]

11. Ismail, I.; Bernal, S.A.; Provis, J.L.; Hamdan, S.; Van Deventer, J.S.J. Microstructural changes in alkali activated fly ash/slag geopolymers with sulfate exposure. Mater. Struct. 2012, 46, 361-373. [CrossRef]

12. Palacios, M.; Alonso, M.; Varga, C.; Puertas, F. Influence of the alkaline solution and temperature on the rheology and reactivity of alkali-activated fly ash pastes. Cem. Concr. Compos. 2019, 95, 277-284. [CrossRef]

13. Juenger, M.; Winnefeld, F.; Provis, J.; Ideker, J. Advances in alternative cementitious binders. Cem. Concr. Res. 2011, 41, 1232-1243. [CrossRef]

14. Murayama, N.; Yamamoto, H.; Shibata, J. Mechanism of zeolite synthesis from coal fly ash by alkali hydrothermal reaction. Int. J. Miner. Process. 2002, 64, 1-17. [CrossRef]

15. Juengsuwattananon, K.; Winnefeld, F.; Chindaprasirt, P.; Pimraksa, K. Correlation between initial SiO $2 / \mathrm{Al}_{2} \mathrm{O}_{3}$, $\mathrm{Na}_{2} \mathrm{O} / \mathrm{Al}_{2} \mathrm{O}_{3}, \mathrm{Na}_{2} \mathrm{O} / \mathrm{SiO}_{2}$ and $\mathrm{H}_{2} \mathrm{O} / \mathrm{Na}_{2} \mathrm{O}$ ratios on phase and microstructure of reaction products of metakaolin-rice husk ash geopolymer. Constr. Build. Mater. 2019, 226, 406-417. [CrossRef]

16. Kaur, M.; Singh, J.; Kaur, M. Microstructure and strength development of fly ash-based geopolymer mortar: Role of nano-metakaolin. Constr. Build. Mater. 2018, 190, 672-679. [CrossRef]

17. Nath, P.; Sarker, P.K. Use of OPC to improve setting and early strength properties of low calcium fly ash geopolymer concrete cured at room temperature. Cem. Concr. Compos. 2015, 55, 205-214. [CrossRef]

18. Palacios, M.; Puertas, F. Effectiveness of mixing time on hardened properties of waterglass-activated slag pastes and mortars. ACI Mater. J. 2011, 108, 73-78.

19. Pouhet, R.; Cyr, M.; Bucher, R. Influence of the initial water content in flash calcined metakaolin-based geopolymer. Constr. Build. Mater. 2019, 201, 421-429. [CrossRef]

20. Lizcano, M.; González, A.; Basu, S.; Lozano, K.; Radovic, M. Effects of Water Content and Chemical Composition on Structural Properties of Alkaline Activated Metakaolin-Based Geopolymers. J. Am. Ceram. Soc. 2012, 95, 2169-2177. [CrossRef]

21. Steins, P.; Poulesquen, A.; Diat, O.; Frizon, F. Structural Evolution during Geopolymerization from an Early Age to Consolidated Material. Langmuir 2012, 28, 8502-8510. [CrossRef]

22. Criado, M.; Fernandez-Jimenez, A.; Palomo, A. Alkali activation of fly ash. Part III: Effect of curing conditions on reaction and its graphical description. Fuel 2010, 89, 3185-3192. [CrossRef]

23. Provis, J.L.; Duxson, P.; Van Deventer, J.; Lukey, G. The Role of Mathematical Modelling and Gel Chemistry in Advancing Geopolymer Technology. Chem. Eng. Res. Des. 2005, 83, 853-860. [CrossRef]

24. Koutnik, P.; Soukup, A.; Bezucha, P.; Safar, J.; Kohout, J. Low viscosity metakaolinite based geopolymer binders. Constr. Build. Mater. 2020, 230, 116978. [CrossRef]

25. Puertas, F.; Varga, C.; Alonso, M. Rheology of alkali-activated slag pastes. Effect of the nature and concentration of the activating solution. Cem. Concr. Compos. 2014, 53, 279-288. [CrossRef]

26. Rashad, A.M. A comprehensive overview about the influence of different admixtures and additives on the properties of alkali-activated fly ash. Mater. Des. 2014, 53, 1005-1025. [CrossRef]

27. Poulesquen, A.; Frizon, F.; Lambertin, D. Rheological behavior of alkali-activated metakaolin during geopolymerization. J. Non-Cryst. Solids 2011, 357, 3565-3571. [CrossRef]

28. Temuujin, J.; Williams, R.P.; Van Riessen, A. Effect of mechanical activation of fly ash on the properties of geopolymer cured at ambient temperature. J. Mater. Process. Technol. 2009, 209, 5276-5280. [CrossRef]

29. Reddy, S.K.; Varaprasad, J.; Reddy, K.N.K. Strength and workability of low lime fly-ash based geopolymer concrete. Indian J. Sci. Technol. 2010, 3, 1188-1189. [CrossRef]

30. Zhang, Z.; Provis, J.L.; Reid, A.; Wang, H. Mechanical, thermal insulation, thermal resistance and acoustic absorption properties of geopolymer foam concrete. Cem. Concr. Compos. 2015, 62, 97-105. [CrossRef]

31. Zhang, H.Y.; Kodur, V.; Wu, B.; Yan, J.; Yuan, Z.S. Effect of temperature on bond characteristics of geopolymer concrete. Constr. Build. Mater. 2018, 163, 277-285. [CrossRef] 
32. Usobiaga, A.; De Diego, A.; Madariaga, J.M.; Rodriguez, A.D.D. Electrical Conductivity of Concentrated Aqueous Mixtures of $\mathrm{HCl}$ and $\mathrm{KCl}$ in a Wide Range of Compositions and Temperatures. J. Chem. Eng. Data 2000, 45, 23-28. [CrossRef]

33. Wachter, R.; Barthel, J. Untersuchungen zur Temperaturabhängigkeit der Eigenschaften von Elektrolytlösungen II. Bestimmung der Leitfähigkeit über einen großen Temperaturbereich. Ber. Bunsenges. Phys. Chem. 1979, 83, 634-642. [CrossRef]

34. Memon, F.A.; Nuruddin, M.F.; Khan, S.; Shafiq, N.; Ayub, T. Effect of sodium hydroxide concentration on fresh properties and compressive strength of self-compacting geopolymer concrete. J. Eng. Sci. Technol. 2013, 8, 44-56.

35. Vance, K.; Dakhane, A.; Sant, G.; Neithalath, N. Observations on the rheological response of alkali activated fly ash suspensions: The role of activator type and concentration. Rheol. Acta 2014, 53, 843-855. [CrossRef]

36. Luhar, S.; Cheng, T.; Nicolaides, D.; Luhar, I.; Panias, D.; Sakkas, K. Valorisation of glass wastes for the development of geopolymer composites-Durability, thermal and microstructural properties: A review. Constr. Build. Mater. 2019, 222, 673-687. [CrossRef]

37. Zhang, D.-W.; Wang, D.-M.; Liu, Z.; Xie, F.-Z. Rheology, agglomerate structure, and particle shape of fresh geopolymer pastes with different $\mathrm{NaOH}$ activators content. Constr. Build. Mater. 2018, 187, 674-680. [CrossRef]

38. Luhar, S.; Cheng, T.-W.; Nicolaides, D.; Luhar, I.; Panias, D.; Sakkas, K. Valorisation of glass waste for development of Geopolymer composites-Mechanical properties and rheological characteristics: A review. Constr. Build. Mater. 2019, 220, 547-564. [CrossRef]

39. Wang, R.; Wang, J.; Dong, T.; Ouyang, G. Structural and mechanical properties of geopolymers made of aluminosilicate powder with different $\mathrm{SiO}_{2} / \mathrm{Al}_{2} \mathrm{O}_{3}$ ratio: Molecular dynamics simulation and microstructural experimental study. Constr. Build. Mater. 2020, 240, 117935. [CrossRef]

40. Shi, C.; Jimenez, A.F.; Palomo, A. Cement and Concrete Research New cements for the 21st century: The pursuit of an alternative to Portland cement. Cem. Concr. Res. 2011, 41, 750-763. [CrossRef]

41. Al Bakria, A.M.; Kamarudin, H.; Binhussain, M.; Nizar, I.; Zarina, Y.; Rafiza, A. The Effect of Curing Temperature on Physical and Chemical Properties of Geopolymers. Phys. Procedia 2011, 22, 286-291. [CrossRef]

42. Kovalchuk, G.; Fernandez-Jimenez, A.; Palomo, A. Alkali-activated fly ash: Effect of thermal curing conditions on mechanical and microstructural development-Part II. Fuel 2007, 86, 315-322. [CrossRef]

43. Criado, M.; Palomo, A.; Jiménez, A.F. Alkali activation of fly ashes. Part 1: Effect of curing conditions on the carbonation of the reaction products. Fuel 2005, 84, 2048-2054. [CrossRef]

44. Tekin, I. Properties of $\mathrm{NaOH}$ activated geopolymer with marble, travertine and volcanic tuff wastes. Constr. Build. Mater. 2016, 127, 607-617. [CrossRef]

45. Arellano-Aguilar, R.; Burciaga-Diaz, O.; Gorokhovsky, A.; Escalante-Garcia, J.I. Geopolymer mortars based on a low grade metakaolin: Effects of the chemical composition, temperature and aggregate:binder ratio. Constr. Build. Mater. 2014, 50, 642-648. [CrossRef]

46. Xu, H.; Van Deventer, J. The geopolymerisation of alumino-silicate minerals. Int. J. Miner. Process. 2000, 59, 247-266. [CrossRef]

47. Nair, D.G.; Vishnudas, S. Geopolymer Binder from Industrial Wastes: A review. Mater. Sci. 2014, 5, $219-225$.

48. Mustafa Al Bakri, A.M.; Kamarudin, H.; Khairul Nizar, I.; Bnhussain, M.; Zarina, Y.; Rafiza, A.R. Correlation between $\mathrm{Na}_{2} \mathrm{SiO}_{3} / \mathrm{NaOH}$ ratio and fly ash/alkaline activator ratio to the strength of geopolymer. Adv. Mater. Res. 2012, 341-342, 189-193.

49. Hardjito, D.; Rangan, B.V. Development and Properties of Low-Calcium Fly Ash-Based Geopolymer Concrete; Curtin University of Technology: Perth, Australia, 2005.

50. Nurruddin, E.A. Methods of curing geopolymer concrete: A review. Int. J. Adv. Appl. Sci. 2018, 5, 31-36. [CrossRef]

51. Zhang, Z.; Wang, H.; Provis, J.L.; Bullen, F.; Reid, A.; Zhu, Y. Quantitative kinetic and structural analysis of geopolymers. Part 1. The activation of metakaolin with sodium hydroxide. Thermochim. Acta 2012, 539, 23-33. [CrossRef]

52. Wan, Q.; Rao, F.; Song, S.; Garcia, R.E.; Estrella, R.M.; Patino, C.L.; Zhang, Y. Geopolymerization reaction, microstructure and simulation of metakaolin-based geopolymers at extended $\mathrm{Si} / \mathrm{Al}$ ratios. Cem. Concr. Compos. 2017, 79, 45-52. [CrossRef]

(C) 2020 by the authors. Licensee MDPI, Basel, Switzerland. This article is an open access article distributed under the terms and conditions of the Creative Commons Attribution (CC BY) license (http://creativecommons.org/licenses/by/4.0/). 